\title{
Customer participation and service outcomes: Mediating role of task-related affective well-being
}

Purpose - This paper contributes to transformative service research by drawing on selfdetermination, elicitation of emotions framework, and feelings-as-information theories to explore how customer participation, task-related affective well-being, customer knowledge, task complexity, and service outcomes relate with each other.

Design/methodology/approach - A synthesis of relevant literature on customer participation and customer well-being reveals a conceptual model with eleven testable propositions.

Findings - The conceptual model shows that task-related affective well-being mediates the link between customer participation and service outcomes. Moreover, customer knowledge and task complexity moderate these links.

Research limitations/implications - An empirically testable conceptual model models the roles of task-related affective well-being, customer knowledge and task complexity in the process by which customer participation influences service outcomes.

Practical implications - Service managers can use the model to design services based on the effects of different types of customer participation on task-related affective well-being.

Originality/value - This paper is one of the first to study the mediating role of task-related affective well-being in the relationship between customer participation and service outcomes. It does so by revealing the differential impact various types of participation have on service outcomes and the moderating role of customer knowledge and task complexity.

Keywords Customer participation, Service outcomes, Task-related affective well-being Paper Type Conceptual paper 


\section{Introduction}

A key challenge facing service firms is encouraging customer participation in the process of creating value because that requires the customer to expend their own energies to help cocreate the service. Despite this, service firms are highly motivated to encourage customer participation as it is considered an important tool to help improve their productivity reflected by both service practitioners and researchers accepting and recognising the active role of customers as resource integrators in value co-creation (Arnould, 2008; Vargo and Lusch 2008). Customer participation is conceptualized as the degree to which customers are involved in the production and delivery of the service by providing information, sharing information, making suggestions and other resources (Dabholkar, 1990; Chan et al., 2010).

Typically, the concept of customer participation is widely embraced by global business giants such as Procter and Gamble, Dell, Starbucks, and Cisco to drive their service agendas (Ramaswamy and Gouillart, 2010) suggesting its universality as part of the service offering. However, customers' willingness to contribute to value co-creation seems less favorable for the firms in relation to what they hope to achieve by actively engaging the customer in the process (Chan et al., 2010). One reason may be an inadequate type of participation requirement from the customer for any given service context and since this may impact desired service outcomes, the aspect of the co-creation process needs a much richer understanding. Differently put, service firms may not fully appreciate the potential impact that various forms of participation may have upon the customers' perception of the quality, value and service experience. Not making this distinction potentially makes customer participation a relatively 'blunt instrument' in creating value, so closer examination of its effects in the service relationship is warranted. 
This is important to understand because there are various types of participation involved in service and each dictates a distinctly different role for the customer during a service encounter; differences that potentially influence how customers view the service offering. Whilst the literature suggests the role of the customer varies - based on the nature of participation, actors, service production, role behaviour, participation process, outcomes of participation, customer input, and level of participation, etc., their combined impact on service outcomes is still a nascent field. Dong and Sivakumar (2017) identified three types of participation, namely mandatory, replaceable and voluntary forms and these are based on the specific nature of participation as well as the actor participating. Conceptually the three types of customer participation vary in the amount of effort required from the customer for them to engage in and experience the service.

Mandatory participation refers to activities or resources that can only be performed or provided by customers and are essential for the service to be produced or delivered. Replaceable participation refers to customer activities or resources that can be performed or provided by customers and/or service providers but are still essential for the service to be produced or delivered. Voluntary participation refers to activities and/or resources that are not essential for service production and/or its delivery, and this is largely performed at the discretion of customers to help improve their service experience. Hence, there is a need to understand the influence of each participation type in a service encounter and in particular how these differences impact service outcomes, as well as intervening variables that could potentially mediate and moderate the inter-relationship between the participation types and these service outcomes.

Accordingly, this paper attempts to conceptualize the differential impact of each form of participation on the potential range of service outcomes desired by the customer, which is distinctly different from previous studies. Typically, these have identified the consequence of 
customer participation on a range of outcomes such as customer satisfaction, perceived service quality, employee satisfaction, efficiency, loyalty and productivity, among others (e.g. Gallan et al., 2013; Ngo and O’Cass, 2013; Cheng and Xue, 2014; Amorim et al., 2014; Dong et al., 2015; Chen and Wang, 2016). Thus, the literature has largely focused on the impact of the construct in relation to outcomes beneficial for the service providers that help the firm to improve their profitability. However, when a customer participates in a service encounter, the concern of the customer are also directly linked to their own personal experiences with the service and/or the value perceived by them. Therefore, such concerns also need to be considered in terms of how they influence outcomes, such as satisfaction, productivity, performance, loyalty, among others. Hence, building on the existing literature on various service outcomes that are relevant to the service provider we also consider additional outcomes; accordingly, we build a model (see figure 1) to reflect these consequences.

Since service consumption dominates the lives of customers today, other factors intrinsically linked to the service experience also play a potential role in helping to shape customer perceptions of the service offering. Typically, customers spent a large amount of time participating in service offerings as well as interacting with service employees, so this ongoing experience is likely to influence their well-being (Rosenbaum et al., 2011). Thus, most service contexts that are directly related to (e.g. nursing, mental health counselling, physiotherapy, etc.) as well as not being specifically connected to (e.g. banking, education, tourism, etc.) well-being potentially have a positive or negative impact on the well-being of the customer in ways not intended (or previously foreseen) by firms (Anderson et al., 2013). Exploring this in more detail has been identified as a priority in the emerging domain of transformative service research, referred to as TSR (e.g., Anderson and Ostrom, 2015).

TSR focuses on the creation of elevating and inspiring changes for the improvement of the well-being of individuals (consumers and employees), families, community, society, and 
ecosystem (Ostrom et al., 2010; Anderson et al., 2013). Well-being includes "physical health (objective and subjective perceptions), mental health (e.g., resilience, stress, and burnout), financial wellbeing, discrimination, marginalization, literacy, inclusion, access, capacity building, and decreased disparity among others” (Anderson and Ostrom, 2015, p.243).

Given the centrality of service consumption (and growing customer participation) in our everyday lives, we thus develop a conceptual model that reveals how customer well-being is influenced by the nature of the tasks they are attempting to accomplish during the service encounter, and how this potentially affects various service outcomes. Although research has attempted to conceptualize the domain of TSR by considering studies on well-being, no prior research has explained the central role of 'task-related affective well-being' (TR-AWB) in the nexus between the different forms of participation on the service outcomes. With this in mind, our conceptual model depicts TR-AWB to play a mediating role between the various forms of customer participation and service outcomes.

We also recognise that factors specific to the customer, firm, context, and situation can intervene in the influence of customer participation on service outcomes. Thus, by reviewing pertinent literature our study reveals the moderation effect of customer knowledge (customerspecific) and task complexity (firm-specific) in the mediated linkage between customer participation, well-being, and service outcomes and, that the impact of such moderation may vary for the different types of participation. Based on this discussion, we address the following research questions in this paper:

$R Q 1$. Do different types of participation (mandatory, replaceable, voluntary) influence service outcomes differently?

$R Q 2$. Does customer participation also influence multiple service outcomes such as customer experience and customer value in addition to the existing outcomes? 
$R Q 3$. Does task-related affective well-being (TR-AWB) mediate the relationship between customer participation and service outcomes?

RO4. Do customer-specific (customer knowledge) and firm-specific (task complexity) factors moderate the mediated relationship between customer participation, task-related affective well-being (TR-AWB) and service outcomes?

By answering these questions, this paper contributes to the services literature by better understanding the mechanism of how there is a differential influence of each participation type on service outcomes. In addition to previously understood service outcomes, customer experience and customer value were also simultaneously considered as service outcomes in the model. Earlier studies support the mediating role of well-being on service outcomes (e.g., Sharma, Kong and Kingshott, 2016) however this paper attempts to explain the moderating influence of customer knowledge and task complexity, and in doing so further extends both the customer participation and well-being literature.

The remainder of the paper is arranged as follows. We first discuss the literature on the five constructs namely customer participation, service outcomes, well-being, customer knowledge, and task complexity and their interlinkages - conceptualized with the support of theories. Next, we develop a conceptual model and offer eleven testable propositions about the interrelationships among constructs - including many direct and indirect effects. Finally, we discuss the implications of the research, its limitations and directions for future research.

\section{Literature review}

In this paper, literature regarding customer participation, service outcomes, and customer well-being were synthesized and analysed to help develop a conceptual model linking these important service constructs. This enabled us to categorize and present the existing literature to identify the relevant gaps. Several studies have focussed on the influence of customer 
participation on a range of service outcomes (e.g., Gallan et al., 2013; Ngo and O’Cass, 2013; Cheng and Xue, 2014; Amorim et al., 2014; Dong et al., 2015; Chen and Wang, 2016). We draw upon these and integrate them into our proposed model.

We also examined the literature related to several TSR service contexts to understand the various types of well-being, and its importance in service encounters to provide a much richer explanation and understanding of how customer participation in service encounters potentially impacts important service related outcomes. Thus, this paper focuses on conceptualizing the mediating role of well-being upon the influence of customer participation on service outcomes with the support of a suitable theoretical background. Accordingly, we discuss the literature regarding customer participation, service outcomes, and well-being to help delineate the gaps that are being explained by our conceptual model. Each of these aspects related to co-created service delivery are discussed next.

\section{Customer participation}

Customer participation is defined as "the degree to which the customer is involved in producing and delivering the service” (Dabholkar, 1990, p. 484). The concept is related to the active role played by the customer in any service encounter (Silpatik and Fisk, 1985). Thus customer participation is the process by which customers take part in the encounter by providing information and knowledge, labour and task performance, and behaviours (Mustak et al., 2016). From the perspective of the service-dominant logic, customers contribute towards co-producing a service by participating proactively during the encounter (Chan et al., 2010). The term “customer participation” has been widely used over a long period in marketing and related disciplines (Mustak et al., 2016). However, terminologies such as customer involvement, co-production, and co-creation, have been used interchangeably with customer participation in various literature, despite being quite different from each other. 
While customer participation captures the crux of customers' involvement in developing goods or services, the extent of such participation can be active (self-check-in at the airport) or passive (being present for the haircut) - which also includes situations without the complete involvement of the customer. Co-production results when the customer collaborates with the firms to produce service, making collaboration and production the two important elements (Vargo and Lusch, 2008). On the other hand, co-creation is based on value creation, but the scope is much broader compared to co-production involving multiple actors contributing to the well-being of each other's (Vargo and Lusch, 2016). However, customer participation is conceptually distinct from these as it does not limit itself to joint production because it includes all forms of potential service interactions the customer can have with the service organization (i.e., customer, joint, and firm production).

We use the typology proposed by Dong and Sivakumar (2017) to help depict customer participation - which is based on the nature of the respective tasks being undertaken by the customer and service organization, manifesting as mandatory participation, replaceable participation, and voluntary participation. Mandatory participation refers to those activities that are performed only by customers and are essential for the delivery of the service. Typically, a mandatory customer input includes people (e.g., the customer's presence at dental clinic), objects (e.g., clothes for tailoring), information (e.g., providing information for tax preparation), and preferences (e.g., choosing a flight for travel). Replaceable participation refers to those essential activities that could be potentially performed by customers as well as service providers meaning the presence of substitutes (in terms of performance) are available to the customer when experiencing the service. The inputs required are similar to mandatory but there is a choice in the actor performing the task (e.g., grocery check-out done by an employee or self-checkout by customer) and this choice is largely at the discretion of the customer. In contrast, voluntary participation refers to activities that are either performed by 
the customers and/or the service providers but are not essential for the service delivery to occur, however, they do potentially help enhance the customer's overall service experience. The decision to incorporate these particular service elements into the service offering, as well as deciding who 'performs' the role is at the sole discretion of the customer. However, these two decisions do not detract from the overall service as they help to augment the offering (e.g., additional legroom during air travel).

\section{--INSERT TABLE 1 HERE--}

The three types of participation place different levels of stress on customers in the process of service consumption, as summarized in Table 1. However, despite this evidence, there is hardly any research on the differences in the influence of the three participation types on the service process and its outcomes. This includes those outcomes that are already studied (e.g., service quality and customer satisfaction) and others that are also important for service customers (e.g., customer perceived value and customer experience). Considering the advance of services scholarship into the domain of TSR, the role played by the different types of participation in influencing the well-being of the customer also holds great importance. This paper addresses these gaps in the literature.

\section{Service outcomes}

The outcomes of customer service experiences could be potentially positive or negative for service providers and/or customers. Ideally, positive outcomes are desirable, and/or even the elimination or reduction of negative outcomes are sought by the service organization. Customer participation could lead to both positive and negative service outcomes thus its role in the provision of the service encounter may not always be a desirable service approach (Chan et al., 2010), meaning its function in the service encounter needs to be understood more clearly. Numerous literature have identified the linear and continuous influence of 
customer participation on service outcomes, as presented in Table 2. Also, the relationship between these was identified to be non-monotonic (Dong et al., 2015). Since satisfaction and perceived service quality are the frequently studied service outcomes in customer participation literature (Cermak et al., 1994; Ennew and Binks, 1999; Claycomb et al., 2001; Auh et al., 2007; Ofir et al., 2009; Gallan et al., 2013; Dong et al., 2015) we also consider these two variables as critical service outcomes resulting from the various forms of customer participation. However, since previous works related to the differential influence of the three types of participation on these and a wider range of important service constructs has not previously been conceptualized in literature, their impact is subsequently modeled herein.

Customer satisfaction is conceptualized as the emotional state of a customer on the evaluation of an interaction experience combining the customer's affective and evaluative aspects of the service encounter (Oliver, 1997). Perceived service quality is considered as the global judgment or attitude towards the service encounter based on customers' beliefs about the service (Parasuraman et al., 1988). Both customer satisfaction and perceived service quality are important and useful indicators of firm performance and hence included in the model. Table 2 presents the relationship that customer participation has with satisfaction and service quality.

\section{--INSERT TABLE 2 HERE--}

To date, studies on customer participation have focused on service outcomes such as satisfaction, service quality, productivity, performance, etc. However, there is little evidence regarding the influence of customer participation on service outcomes from the perspective of the customer in terms of their combined experiences towards, and perceived value of the service offering. Hence, in this paper, we attempt to incorporate these outcomes into our proposed model to help better understand the influence of participation. Customer value is depicted as the outcome of the total evaluation of the utility of a product/ service by the customer based on their perception (Zeithaml, 1988; Woodruff, 1997; Verma and Plaschka 
2003). Customer experience is conceptualised as the customer's subjective response or assessment of all attributes based on their direct and indirect interaction between the firm and the customer (Lemke et al., 2011; Klaus and Maklan, 2012).

Customer participation is part of a journey that customers go and thus comprises a distinct set of processes encountered by the customer. Typically, when the customer participates in a service encounter, they enter the servicescape in an attempt to get a service delivery. For such delivery to happen, all customers must embark upon this service journey and in doing so are confronted by a service offering that potentially comprises various levels of participation which in turn may affect their current physiological or psychological state of well-being. We postulate that the nature of these 'participation episodes' potentially influences their perceptions about service outcomes. In the current paper, we depict this customer journey in terms of the nature of the participation process they are faced with, thus for every customer the individual type of participation, the nature of activities (essential, not essential) and the actors (customers, employee) potentially varies. Such variation has a differential influence on the customer throughout the journey - affecting their well-being and in turn service outcomes.

\section{Task-related affective well-being}

Well-being comprises a holistic construct comprising of moods and emotions (Schwarz and Clore, 1996), happiness (Diener and Lucas, 1999), life satisfaction (Ryan et al., 2008) in addition to physical and mental elements. Subjective well-being of an individual is conceptualized as the degree to which individual experiences positive or a negative affect during their life (Diener et al., 1999; Zhong and Mitchell, 2012). This is reflected in the current priorities in the domain of TSR that emphasizes the need for researching and better understanding services that improve and transforms the lives of customers thus gaining ongoing interest of scholars (Sirgy and Lee, 2008; Rosenbaum et al., 2011; Anderson et al., 2013). TSR literature facilitates understanding the importance of well-being in service 
contexts because it is conceptualized to investigate the relationship between service experiences and individual well-being (Anderson, 2013).

The major goal of TSR is to explore and examine well-being implications of services, and this domain is aptly defined as "the integration of consumer and service research that centers on creating uplifting changes and improvements in the well-being of consumer entities: individuals (consumers and employees), communities and the ecosystem” (Anderson et al., 2013, p.1204). TSR highlights the central roles of individual well-being during service encounters (Anderson and Ostrom, 2015) because the customers' continuous interaction with services may affect their well-being positively or negatively. Hence, our study draws directly upon the underlying theme of TSR paradigm to explain the central role played by well-being during the service encounter; one that is potentially typified by a customer journey involving the different types of customer participation. Since various constructs mediate the influence of customer participation on service outcomes, such as value creation of customer and employees (Chan et al., 2010), service attribution (Chen, 2018), among others, we postulate that well-being also plays a central role in the link between participation and a range of service outcomes.

Conceptually, well-being is approached by two traditions, hedonic and eudaimonic in the literature. The concept of hedonic well-being is based on sensory pleasure whereby positive emotions and better life satisfaction leads an individual to experience happiness (Kahnemann et al., 1999; Diener et al., 1999; Carruthers and Hood, 2004). Hedonic experiences are transitory in nature and help to increase the well-being of an individual temporarily (Deci and Ryan, 2008). On the other hand, eudaimonic well-being embodies life's purpose (Ryff and Singer, 2000; Deci and Ryan, 2008) where the individual utilizes their full potential and achieve improvement.

Zhong and Mitchell (2012) identified the significant influence of subjective well-being on the consumption process. Moreover, TSR suggests that well-being could be important in 
every type of service context, but to date the attempts to conceptualize the role of the construct in service encounters comprising the various forms of participation is limited. Hence, in this paper, we decompose participation into its constituent parts and consider their impact on well-being as well as how that impacts service related outcomes. As participation types reflect the customers' tasks in hand that could impart or trigger events impacting the well-being of the person influencing their service outcome, we depict well-being from the perspective of task-related affective well-being (TR-AWB). Next, we discuss all the constructs used in our proposed conceptual model.

\section{Conceptual model development}

The paper focusses on conceptualizing the influence of different types of customer participation on salient service outcomes and the role played by the customer's task-related affective well-being (TR-AWB) on these outcomes. It also encapsulates the role played by customer-specific (customer knowledge) and firm-specific (task complexity) factors on the proposed participation-task related affective wellbeing-service outcome link. In order to do this several theories were reviewed and incorporated herein to help explain the conceptual model (Figure 1). Based on this body of literature a number of propositions showing the interrelationships between constructs are offered.

\section{--INSERT FIGURE 1 HERE--}

\section{Customer participation and service outcomes}

The impact of the three types of participation (i.e., mandatory, replaceable, and voluntary) on both customer well-being and critical service outcomes is proposed herein to be different from each other; thereby justifying the need to conceptualize customer participation as being multi-faceted in order to tease out these variations. We depict these service outcomes to comprise service quality and customer satisfaction, customer value, and customer experience. 
Reactance theory (Brehm, 1966) helps to understand the differential influence of participation types on all four of these service outcomes. Reactance theory is social psychological in nature that helps explain the reaction of an individual when their freedom to choose is restricted (Brehm, 1966). When there is a threat against an individuals' freedom to engage in a specific behaviour, the threatened behaviour becomes more attractive. Under any specific situation, two conditions arise and must be satisfied for reactance to occur, namely: (a) an individual must assume a measure of freedom to act, and (b) there must be some threat imposed upon that freedom (Lessne and Venkatesan, 1989).

Typically, from the reactance theory perspective mandatory participation greatly affects the customers' freedom to act during a service encounter as they need to undertake this form of activity to experience the service encounter but have no choice in the matter. By posing a threat to their freedom to act (i.e., restrict choices) this in effect means mandatory participation is the least attractive option to the customer when compared to replaceable participation as the latter comprises more customer freedom, due to it also being potentially performed by the service employee. From a reactance theory perspective, the most attractive action needed to be performed by the customer is voluntary participation as this represents complete freedom of choice. Hence, we posit that customers would perceive voluntary participation better than replaceable participation followed by mandatory participation.

P1. Customer participation has a positive impact on service outcomes, and the effect is greater for voluntary participation followed by replaceable and mandatory participation respectively.

\section{Customer Participation, Well-Being and Service Outcomes}

To conceptualise the influence of customer participation on task-related affective well-being (TR-AWB) we draw support specifically from self-determination theory (SDT) (Ryan and 
Deci, 2000) and the framework offered by McColl-Kennedy et al. (2017) on the elicitation of emotions on the service experience. According to Ryan and Deci (2000), SDT is a well thought out organismic theory of motivation and well-being. It assumes individuals have predispositions to grow, master challenges, and integrate new experiences into a coherent sense of self thus "humans are active, growth-oriented organisms who are naturally inclined towards integration of their psychic elements into a unified sense of self and integration of themselves into social structures" (Deci and Ryan, 2000, p.229). SDT identified that individuals have innate psychological needs that upon satisfying/thwarting can enhance or diminish motivation, mental health and well-being (Ryan and Deci, 2000).

SDT suggests a similar underlying mechanism for both motivation and well-being (Deci and Ryan, 1985) and through that scholars were able to articulate the theory of psychological needs that form the underpinning of personal growth, integrity, and well-being (Deci and Ryan, 2000). Deci and Ryan (2000) suggest that when basic needs (i.e., physiological and psychological) are satisfied this stimulates well-being and if not satisfied, potentially leads to ill-being. These needs comprise of autonomy, competence, and relatedness (Levesque et al., 2004). During customer participation, customers experience self-endorsement and discretion in their behaviour and take an internal locus of control from the perspective of attribution. Since customers participate out of genuine interest and needs, it promotes a sense of autonomy and freedom. While participating in the process and journey related to service creation, customers exercise, maintain and enhance their capabilities to adapt to a complex environment. Hence, when the customer feels confident in their behaviour that would help to further encourage a sense of competence in their ability to perform their role in the service. By participating in the service, customers also feel connected to others, and, when the customer experiences these particular psychological attachments it acts to boost their sense of relatedness (Engstrom and Elg, 2015; Gong et al., 2016). By adopting Ryan and Deci’s 
(2000) self-determination continuum, Engstrom and Elg (2015) were thus able to demonstrate the taxonomy of participation based on motivation to help show the influence of customer participation on well-being.

In a more recent study, McColl-Kennedy et al. (2017) have conceptualized the influence of events on emotional well-being of the customer in a healthcare service context. Their framework suggests that a 'trigger event' can lead to a dynamic series of subsequent emotional experiences, represented as sub-events comprising emotional relevance. This set of events triggers a potential suite of discrete (positive and/or negative) emotions that are likely to be short-term and transient in nature, and these can influence well-being during the customer's participation journey that would be experienced during the service encounter. Hence, we propose that:

P2a. Customer participation has a positive impact on task-related affective well-being TRAWB), and furthermore the effect is greater for voluntary participation followed by replaceable and mandatory participation respectively.

The information processed from the well-being of the customer helps in making judgements (Schwarz, 2012). Feelings as information theory (FIT) is one of the most influential explanations for the cognitive consequences of the affect (Schwarz and Clore, 2003). According to Schwarz and Clore (1996), FIT helps to better explain the role of experience, cognitive and somatic components of feelings in making judgements. The experiences component of feelings includes affective experience (e.g., emotions and moods), bodily experience (e.g., hunger, pain, psychological arousal) and cognitive experience (e.g., metacognitive experience of accessibility, processing fluency). The cognitive component explains the storage and access of these experiences, based upon an individual's memory of previous events. The somatic component reflects the feeling of body movements processed 
for judgements. Hence, the theory assumes feelings act as a potential source of information to enable an individual in the judgement process.

Therefore, by considering FIT as the lens to view the process of customer participation during a service encounter, this theory helps to better explain the impact that the level and nature of their feelings of well-being play when making judgments about potential service outcomes. Typically, when a customer participates in a service encounter the direct effect of their moods, emotions, metacognitive experiences and bodily sensations help temper the customer's judgement accordingly. Thus, based on the positive judgement of well-being, the service outcomes are most likely to be considered positive whereas the negative judgement of well-being impacts the service outcomes adversely. Hence, this study draws upon FIT to explain the linkage of TR-AWB on various service outcomes, in addition to the influence of customer participation on service outcomes. Hence, we propose:

P2b. Task-related affective well-being has a positive effect on service outcomes.

Based on the above discussion, we argue that TR-AWB is theoretically supported to mediate the influence of participation on service outcomes. TR-AWB comprises affective, mental, and physical well-being of the customers that occurs during their service experience, facilitated by one or more of the forms of participation. Our depiction of TR-AWB as a mediator draws on previous work in OB/HR areas that similarly show employee well-being as a mediator between management practices and organisational performance (Wood et al., 2012), as well as intervening between internal service quality and employee performance (Sharma et al., 2016). Introducing TR-AWB as a mediator in a consumer research setting is a major contribution because it looks beyond the more commonly displayed roles of TR-AWB as being antecedent (Zhong and Mitchell, 2012) and/or an outcome (Devezer et al., 2014; Zhong and Mitchell, 2010) based construct. Hence, we propose: 
P2c. Task-related affective well-being (TR-AWB) partially mediates the positive influence of customer participation on service outcomes, and the effect is greater for voluntary participation followed by replaceable and mandatory participation respectively.

\section{Customer knowledge and task complexity}

Prior research shows that participation is a process in which the degree of a consumers' participation readiness (Dong et al., 2015), and service output (Dong and Sivakumar, 2015) were considered as the moderators in the relationship between customer participation and service outcomes. Also, power distance (Chan et al., 2010), individualism/ collectivism (Chan et al., 2010), self-efficacy (Chen, 2018), among others were considered to moderate the mediated path between customer participation and service outcomes. Since several factors are shown to influence the relationship between participation and service outcomes, we propose herein that both a customer-specific (i.e., customer knowledge) and a firm-specific (i.e., task complexity) moderator will also play a role in influencing the link between customer participation and service outcomes. We argue that elevated (or limited) previous customer knowledge about what to do during a service encounter helps (or hinders) participation in the service encounter, whereas task complexity reflects the service design that is 'controlled' by the firm and this can either enhance or thwart the participation process.

This premise we make is also based upon previous literature. Typically, customer knowledge is a customer-specific factor and conceptualized as perceived knowledge of the customer regarding the service encounter, enabling them to participate effectively (Chiou et al., 2002; Meuter et al., 2005). Bowen (1986) explains ways to improve customer participation by providing more awareness or knowledge from a human resource perspective. Based on the self-efficacy theory (Bandura, 1977) better knowledge about the service will enhance the customer's beliefs in their innate ability to process and achieve the goal of 
performing the service effectively to the customer's satisfaction. Hence, we propose that customer knowledge has a positive influence on service outcomes, as follows:

P3a. Customer knowledge has a positive effect on service outcomes.

We use elaboration likelihood model (ELM; Petty and Cacioppo, 1986) to argue that the strength of the relationship that customer participation has on TR-AWB and service outcomes will be moderated by the level of customer knowledge (high vs. low). The ELM framework helps explain how persons organize, categorize and understanding persuasive communications, meaning the impact of customers to participating in the service encounter is also contingent on their prior knowledge of what needs to be done, and to do it. Under the guise of ELM, the extent of such knowledge determines the route of processing available information at the point of the service encounter, and this can be either central or peripheral in nature. A central route results when an individual gives thoughtful consideration to the merits of information available, suggesting prior knowledge of what is expected during the encounter, whereas the peripheral route results from a simple cue without scrutinizing the merits of available information (p. 125).

This means that when customer knowledge is high about what to do and how to do it, the processing of knowledge is likely to take place via the central route. Conversely, if their knowledge regarding the service and associated role to play is low, the processing will take a peripheral route; and, hence potentially reduce the strength of proposed relationships (P1 \& P2a) in the model. A high customer knowledge/ central processing route is completely based on the information in hand leading to an increase in the strength of these two relationships. On the other hand, a low customer/ peripheral route is based on peripheral service related cues are likely to reduce the strength of these two relationships. Hence, higher customer knowledge will interact with customer participation to influence the TR-AWB and service 
outcome positively, whereas a lower customer knowledge will interact with customer participation to reduce its impact on TR-AWB and service outcomes. Hence, we propose:

P3b. The positive effect of customer participation on service outcomes is stronger (weaker) for higher (lower) levels of customer knowledge, and the effect is greater for voluntary participation followed by replaceable and mandatory participation respectively.

P3c. The positive effect of customer participation on task-related affective well-being (TRAWB) is stronger (weaker) for higher (lower) levels of customer knowledge, and the effect is greater for voluntary participation followed by replaceable and mandatory participation respectively.

In a service encounter, the task at hand facing the customer is very important in considering the nature of their participation because the degree of complexity may influence their how they engage - resulting in a positive or negative impact on the customer's view of service outcomes. This is because task complexity is conceptualised as the degree of difficulty of a task and based on the characteristics of the task such as the psychological experience of the customer and the customer-task interaction (Campbell, 1988). According to social cognitive theory (Bandura, 1977), the customer may choose a simple task over a complex task because the former will lead to a more certain outcome - reducing the risk of failure. As the complexity of the task increases, it influences the service outcome negatively. Hence,

P4a. Task complexity has a negative effect on service outcomes.

Based on social cognitive theory (Bandura, 1977) we anticipate the strength of relationship from customer participation towards TR-AWB; customer participation towards service outcomes; and, TR-AWB towards service outcomes will be moderated by task complexity (high vs. low). Task complexity interacts with customer participation; high task complexity 
will make the participation difficult compared to low task complexity. This is underpinned by Wood (1986) who argues that task complexity is based on information cues an individual needs to process in performing a task. The number of distinct cues an individual must process for successful task completion is the function of task complexity.

Previous literature on task complexity specifies that high task complexity demands more cognitive resource due to the increase in information processing requirements (e.g. Zigurs and Buckland 1998; Speier and Morris 2003; Klemz and Gruca 2003). The cognitive capacity of the individual may be adversely influenced when the information processing exceeds a certain limit, leading to a negative performance (Norman and Bobrow 1975; Kamis et al., 2008). Hence the task complexity is likely to moderate the mediated path of customer participation - TR-AWB - service outcome relationship. Hence, we propose:

$P 4 b$. The positive effect of customer participation on service outcomes is stronger (weaker) for lower (higher) task complexity, and the effect is greater for voluntary participation followed by replaceable and mandatory participation respectively.

P4c. The positive effect of customer participation on task-related affective well-being is stronger (weaker) for lower (higher) task complexity, and this effect is greater for voluntary participation followed by replaceable and mandatory participation respectively.

P4d. The positive effect of task-related affective well-being on service outcomes is stronger (weaker) for lower (higher) task complexity.

As previously indicated customer participation is becoming more important in the service industry, playing a critical role in service delivery and associated outcomes. As suggested by the literature, asking the customer to participate in a service encounter may affect their wellbeing; whereby some customers may find it positive while others may not want to participate 
and/or even encounter a complex task. Based on the theoretical underpinnings and existing literature related to the topic we articulate and present herein, it is apparent that those constructs identified in our proposed conceptual model play an important role in helping shape customer expectations about the service offering. There are naturally a range of implications for this, and some of these are discussed in the next few sections.

\section{Discussion}

This conceptual paper builds on the emergent domain of TSR by specifically investigating the influence of the various types of participation on customer well-being and service outcomes. Whilst prior studies have identified the influence of service outcomes based on the levels of participation in the service relationship, in this article, we consider the influence of mandatory, replaceable and voluntary participation on a suite of important service outcomes. In doing, so we extend the dominant focus on service outcomes, currently reported in the literature, to also consider customer value and customer experience. Moreover, this paper simultaneously investigates the mediating role of task-related affective well-being (TRAWB) as well as the moderating role of customer knowledge and task complexity on the link between customer participation and the identified service outcomes.

\section{Theoretical contribution}

This paper makes four specific and a number of general theoretical contributions. First, by building on the participation literature related to service outcomes we help to identify the potential influence that each type of customer participation potentially has on a range of service outcomes. In particular, existing literature on customer participation has identified three different types, namely: mandatory, replaceable and voluntary participation (Dong and Sivakumar, 2017). However, since there is no literature conceptualizing the differential influence of the three types of participation on important service outcomes we do this by 
showing precisely how participation influences four critical service outcomes (i.e., service quality, customer satisfaction, customer value, and customer experience) differently.

Second, (as identified above) the proposed relationship between customer participation and service outcomes embodies a wider number of service outcomes than those currently depicted in the literature into one concise model. More specifically, we contribute to the existing literature by also including customer experience and customer value as desirable outcomes. Third, the role of TR-AWB as a mediator in the nexus between customer participation and service outcomes enables our depiction of participation to transcend into literature associated with the TSR domain. To the best of our knowledge, this is one of the first studies to investigate the role of TR-AWB in the relationship between customer participation and service outcomes that emanate directly from the service encounter.

Fourth, the inclusion of customer knowledge and task complexity as moderators helps to extend the customer participation and well-being literature. Although existing literature has depicted moderators in that relationship, this study is the first to conceptualize the role that customer knowledge and task complexity plays. Moreover, this study also considers the moderating role of customer knowledge and task complexity in the mediated path comprising the customer participation - TR-AWB - service outcome relationship.

More generally, a contextual contribution is made to the literature by adopted the framework on the elicitation of emotions in healthcare service experience (McColl-Kennedy et al. 2017) to show how this can be extended to all service encounters that encapsulate ‘trigger events' resulting from the customers' participation, that is performing a task in the value creation process. In a similar vein, FIT and SDT are used to further explain the influence of well-being on service outcomes. The former is used widely in the research related to psychology, personality, education, consumer psychology, but its use is limited in 
services literature. Likewise, SDT is used predominantly in healthcare to explain well-being we make a contextual contribution to both FIT and SDT, within the general services context.

Finally, our theoretical contribution is summarized in 11 testable propositions included in our proposed conceptual model. Based on the SDT and FIT we proposed the mediating role of TR-AWB in the influence of participation on various service outcomes. We also incorporate reactance theory to help conceptualize the influence of three types of participation on the service outcomes. With the help of self-efficacy theory, elaboration likelihood model, and social cognition theory, we posited the influence of moderators on the mediated relationship of customer participation - TR-AWB - service outcomes. Like any study of this kind, the learnings we share poses a number of potential managerial implications and some of these are now discussed prior to suggesting limitations and directions for future research.

\section{Managerial implications}

The proposed model contributes to service manager understanding of how customer participation and well-being potentially impacts their service operations by providing several useful insights that could help enhance value to both the service organization and their customers. By placing focus on the differential influence that various types of participation have on desired service outcomes this research indicates the need for managers to distinguish between the various forms of participation. This is an important managerial mindset to have because differentiating between mandatory, replaceable and voluntary forms is requisite in a modern service environment when service organizations wish to optimise their customer experiences during the service journey. Typically, we reveal those organizations that can categorize services based on the most suitable participation type (for any given customer and service setting) in their suite of offerings will be able to optimise their influence on the customer to help attain desirable service outcomes. 
Also, if the service organization can recognise the specific nature and level of voluntary participation their customers are willing to undertake themselves during the service encounter, they can better understand how to influence them into taking up more voluntary participation. This uptake can be enhanced further by offering incentives such as loyalty programs, limited access to customer clubs, access to experience special benefits on offer, etc., when customers themselves undertake voluntary tasks. Once the majority of customers adopt a specific task initially regarded as a voluntary element in the offering - then that task could be easily converted into a mandatory form as the customer becomes more familiar with, and accepting to undertake the task themselves, particularly if doing so enhances their overall service experience.

We highlight the central importance of task-related affective well-being in the process of consuming services and through that its influence on service outcomes; hence, decision makers need to be cognisant of the service conditions leading to improved/diminished wellbeing. Our research depicts well-being to be largely a function of the type of participation customers undertake, meaning that the overall design of the service operation is critical to long-term success. Thus in order to attain and sustain the desired outcomes, and through that elevated levels of organizational profitability, service organizations must concurrently cater to customers that are willing to take the responsibility to participate from those that are not. In a nutshell, this potentially means initially minimising mandatory participation (as far as practicable) at the expense of providing their customers with replaceable and voluntary participation options during the critical service encounter. The key challenge facing managers then is how to encourage more customer to engage in tasks and/or 'convert' their customers into those willing to undertake more tasks in the voluntary and replaceable forms of participation, rather than simply engaging service staff to do it for them.

This is important for service managers to understand because when their customers gradually become accustomed to experiencing participation for themselves (this could be 
through replaceable and voluntary forms), then the service organization could progressively introduce more mandatory forms across their suite of participation types. One way to do this is to make sure that when customers are at the critical point of interacting with the service organization, skilled service staff are in the near vicinity to assist them. Having staffs that are perceptive enough to observe customers and sense whether they become frustrated enables the organization to 'intervene' and help reduce the level of discouragement customers potentially have towards participating. This helps avoid customers simply asking staff to do the task for them as it provides the opportunity for staff to show customers how to do the task, rather than doing it for them. This has the added benefit of helping customers new to the co-creation process, or those not confident enough in what they are doing to take on more responsibility in co-creating the service. Overall, this would help optimize efficiencies at the point of the service encounter, as well as helping enhance the customer experience.

Moreover, since we also reveal that customer knowledge and task complexity has both a direct and indirect impact on service outcomes both of these aspects must be factored into the service design. Clearly, if the operation is too complex at the point when and where customers are expected to participate, then this will negatively impact their views in relation to service outcomes. If operational efficiencies are desired by getting customers to choose to play a role in the domains of replaceable and voluntary participation, then managers should be aware that complex tasks might encourage customers to ask service staff to do the role, as would be the case in these two forms of participation. From an organizational perspective, this could be counterproductive and compromise the main aim of introducing different types of customer participation in the service offering, which is to help improve efficiencies.

Service organizations therefore need to ensure tasks are not complex, and in the very least ensure service staff are also available during the service encounter to monitor the customers and help educate them on what to do. This is particularly critical when new services and 
participation tasks are being introduced into the operation as it provides customers with a critical opportunity to learn what to do and through that become more accepting of undertaking the task. Furthermore, strategies must be employed that help improve customer knowledge about how they can participate in the process of co-creation the service as well as the benefits their participation would provide. For example, letting customers know that precheck ins or self-service check-in activities that can be undertaken by them prior to taking a flight will not only provide them convenience benefits but in this particular example, they could 'queue-jump' to get their desired seat on the airplane. Finally, and in general terms, our proposed model will help motivate service providers to identify the best-suited participation process to yield positive customer well-being that also accounts for the complexity of the task and the customers' knowledge about the task. This will enhance the value perceived by the customers and ensure a greater quality, experience, and satisfaction to the customers, providing a net benefit to the service organization.

\section{Limitations and future research}

Our proposed model raises some important questions and methodological challenges for future research. First, this conceptual paper provides arguments that require empirical testing of the overall conceptual model and underlying propositions, requiring psychometrically sound measures for all constructs. We recommend adapting the existing reliable and valid measures for this purpose, such as customer participation (Yim et al., 2012), TR-AWB (Zhong and Mitchell, 2010, 2012), customer knowledge (Gurhan-Canli, 2003), task complexity (Burnham et al., 2003), perceived service quality (Zeithaml et al., 1996), customer satisfaction (Voss et al., 1998), customer value (Ruiz et al., 2010), customer experience (Anderson and Smith, 2016). Moreover, many of these constructs may correlate with each other, hence future research will also need to establish construct (convergent and 
discriminant), nomological, and predictive validity for all these new measures besides controlling for common method variance in their measurement.

\section{--INSERT TABLE 3 HERE--}

The conceptual model includes one customer specific and one firm-specific moderator, but additional moderators that can potentially be gleaned from the literature that are also likely to influence the link between constructs when empirically testing the model. The model proposed in this study is for service encounters in general. However, moderators that are related to a particular service setting could be explored for contextualizing the model for specific services. Situations could also affect the way a customer participates in a service encounter, and hence further research could involve the situation specific factors that may influence the relationship between model constructs. Further attention is also needed on the conceptual and operational definitions of customer well-being, as it may be considered as a higher dimensional construct, and thus future studies can also explore the influence of customer participation on the factors of well-being to identify what aspects of well-being is getting more affected. Even though more and more research including well-being are studied in a wider variety of service contexts specifically related to health care (e.g., nursing, physiotherapy, psychological services, etc.), those contexts unrelated to health and well-being (e.g., education, financial, tourism, etc) could also be used to explore the influence on wellbeing when the customers participate in the service offering.

Finally, the well-being of customers in the service encounter is gaining more traction and attention in the literature, and through our study we are able to help conceptualise further how customer participation remains one major reason influencing their well-being. Table 3 highlights potential avenues for further well-being based research. Hence, any further studies we highlight in this area of growing importance will help scholars and practitioners better understand this emergent service domain. 


\section{References}

Anderson, L. and Ostrom, A. L. (2015), “Transformative Service Research: Advancing our knowledge about service and well-being”, Journal of Service Research, Vol.18 No. 3, pp. 243-249.

Anderson, L., Ostrom, A. L., Corus, C., Fisk, R. P., Gallan, A. S., Giraldo, M., Mende, M., Mulder, M., Rayburn, S.W., Rosenbaum, M. S. and Shirahada, K. (2013), "Transformative service research: An agenda for the future”, Journal of Business Research, Vol. 66 No. 8, pp. 1203-1210.

Anderson, S. T. and Smith, J. S. (2016), “An empirical examination of the impact of tridyadic fit on the service experience”, Journal of Service Management, Vol. 27 No. 3, pp. 299-319.

Arnould, E. J. (2008), “Service-dominant logic and resource theory”, Journal of the Academy of Marketing Science, Vol. 36 No. 1, pp. 21-24.

Auh, S., Bell, S. J., McLeod, C. S. and Shih, E. (2007), “Co-production and customer loyalty in financial services”, Journal of Retailing, Vol 83 No. 3, pp. 359-370.

Bandura, A. (1977), "Self-efficacy: Toward a unifying theory of behavioral change”, Psychological Review, Vol. 84 No. 2, pp. 191-215.

Bansal, H. S., Taylor, S. F. and St. James, Y. (2005), “’Migrating' to new service providers: Toward a unifying framework of consumers' switching behaviors”, Journal of the Academy of Marketing Science, Vol. 33 No. 1, pp. 96-115.

Bendapudi, N. and Leone, R. P. (2003), "Psychological implications of customer participation in co-production”, Journal of Marketing, Vol. 67 No. 1, pp. 14-28.

Bitner, M. J., Faranda, W. T., Hubbert, A. R. and Zeithaml, V. A. (1997), “Customer contributions and roles in service delivery", International Journal of Service Industry Management, Vol. 8 No. 3, pp. 193-205.

Bolton, R. and Saxena-Iyer, S. (2009), "Interactive services: A framework, synthesis and research directions”, Journal of Interactive Marketing, Vol. 23 No. 1, pp. 91-104.

Bowen, D. E. (1986), "Managing customers as human resources in service organizations", Human Resource Management, Vol. 25 No. 3, pp. 371-383.

Brehm, J. W. (1966), A theory of psychological reactance, Academic Press, New York, NY.

Burnham, T. A., Frels, J. K. and Mahajan, V. (2003), “Consumer switching costs: A typology, antecedents, and consequences”, Journal of the Academy of Marketing Science, Vol. 31 No. 2, pp. 109-126.

Burroughs, J. E. and Rindfleisch, A. (2002), "Materialism and well-being: A conflicting values perspective”, Journal of Consumer Research, Vol. 29 No. 3, pp. 348-370. 
Campbell, D. J. (1988), “Task complexity: A review and analysis”, Academy of Management Review, Vol. 12 No. 1, pp. 40-52.

Carruthers, C. P. and Hood, C. D. (2004), “The power of the positive: Leisure and wellbeing”, Therapeutic Recreation Journal, Vol. 38 No. 2, pp. 225-245.

Cermak, D. S., File, K. M. and Prince, R. A. (1994), “Customer participation in service specification and delivery”, Journal of Applied Business Research, Vol. 10 No. 2, pp. 90-90.

Chan, K. W., Yim, C. K. and Lam, S. S. (2010), "Is customer participation in value creation a double-edged sword? Evidence from professional financial services across cultures", Journal of Marketing, Vol. 74 No. 3, pp. 48-64.

Chen, C. F. and Wang, J. P. (2016), "Customer participation, value co-creation and customer loyalty: A case of airline online check-in system”, Computers in Human Behavior, Vol 62, pp. 346-352.

Chen, C. Y. (2018), "How customer participation influences service failure attribution: The moderating effect of self-efficacy”, Journal of Service Theory and Practice, Vol. 28 No. 3, pp. 298-314.

Cheng, P. and Xue, W. (2014), “Corporate image, customer participation and service quality: From social identity theory perspective”, in, Service Systems and Service Management (ICSSSM), 2014 11th International Conference, IEEE, pp. 1-5.

Chiou, J. S., Droge, C. and Hanvanich, S. (2002), "Does customer knowledge affect how loyalty is formed?” Journal of Service Research, Vol. 5 No. 2, pp. 113-124.

Claycomb, C., Lengnick-Hall, C. A. and Inks, L. W. (2001), “The customer as a productive resource: A pilot study and strategic implications”, Journal of Business Strategies, Vol. 18 No. 1, pp. 47-69.

Dabholkar, P. (1990), "How to improve perceived service quality by improving customer participation”. In, Dunlap, B.J., Ed., Developments in Marketing Science, Academy of Marketing Science, Cullowhee, pp. 483-487.

Davis, B. and Pechmann, C. (2013), "Introduction to the special issue on transformative consumer research: Developing theory to mobilize efforts that improve consumer and societal well-being”, Journal of Business Research, Vol. 66 No. 8, pp. 1168-1170.

Deci, E. L. and Ryan, R. M. (1985), Intrinsic motivation and self-determination in human behaviour, Plenum, New York, NY.

Deci, E. L. and Ryan, R. M. (2000), "The "what" and "why" of goal pursuits: Human needs and the self-determination of behaviour", Psychological Inquiry, Vol. 11 No. 4, pp. 227-268.

Deci, E. L. and Ryan, R. M. (2008), "Facilitating optimal motivation and psychological wellbeing across life's domains”, Canadian Psychology, Vol. 49 No. 1, pp. 14-23. 
Devezer, B., Sprott, D. E., Spangenberg, E. R. and Czellar, S. (2014), “Consumer well-being: Effects of sub goal failures and goal importance”, Journal of Marketing, Vol. 78 No. 2, pp. 118-134.

Diener, E., Suh, E. M., Lucas, R. E. and Smith, H. L. (1999), "Subjective well-being: Three decades of progress”, Psychological Bulletin, Vol. 125 No. 2, pp. 276-302.

Dong, B. (2015), "How a customer participates matters: "I am producing” versus "I am designing”, Journal of Services Marketing, Vol. 29 No.6/7, pp. 498-510.

Dong, B. and Sivakumar, K. (2015), "A process-output classification for customer participation in services”, Journal of Service Management, Vol. 26 No. 5, pp. 726-750.

Dong, B. and Sivakumar, K. (2017), “Customer participation in services: Domain, scope, and boundaries”, Journal of the Academy of Marketing Science, Vol. 45 No. 6, pp. 944-965.

Dong, B., Sivakumar, K., Evans, K. R. and Zou, S. (2015), “Effect of customer participation on service outcomes: The moderating role of participation readiness", Journal of Service Research, Vol. 18 No. 2, pp. 160-176.

Engström, J. and Elg, M. (2015), “A self-determination theory perspective on customer participation in service development”, Journal of Services Marketing, Vol. 29 No. 6/7, pp. 511-521.

Ennew, C. T. and Binks, M. R. (1999), "Impact of participative service relationships on quality, satisfaction and retention: an exploratory study”, Journal of Business Research, Vol. 46 No. 2, pp. 121-132.

Flores, J. and Vasquez-Parraga, A. Z. (2015), “The impact of choice on co-produced customer value creation and satisfaction”, Journal of Consumer Marketing, Vol. 32 No. 1, pp. 15-25.

Gallan, A. S., Jarvis, C. B., Brown, S. W. and Bitner, M. J. (2013), “Customer positivity and participation in services: An empirical test in a health care context", Journal of the Academy of Marketing Science, Vol. 41 No. 3, pp. 338-356.

Gong, T., Choi, J. N. and Murdy, S. (2016), "Does customer value creation behavior drive customer well-being?” Social Behavior and Personality: An International Journal, Vol. 44 No. 1, pp. 59-75.

Gürhan-Canli, Z. (2003), "The effect of expected variability of product quality and attribute uniqueness on family brand evaluations”, Journal of Consumer Research, Vol 30 No. 1, pp. 105-114.

Halbesleben, J. R. and Buckley, M. R. (2004), "Managing customers as employees of the firm: New challenges for human resources management”, Personnel Review, Vol. 33 No. 3, pp. 351-372.

Haumann, T., Güntürkün, P., Schons, L. M. and Wieseke, J. (2015), “Engaging customers in coproduction processes: How value-enhancing and intensity-reducing communication strategies mitigate the negative effects of coproduction intensity", Journal of Marketing, Vol. 79 No. 6, pp. 17-33. 
Heidenreich, S., Wittkowski, K., Handrich, M. and Falk, T. (2015), “The dark side of customer co-creation: exploring the consequences of failed co-created services”, Journal of the Academy of Marketing Science, Vol. 43 No. 3, pp. 279-296.

Kahneman, D., Diener, E. and Schwarz, N. (1999), Well-being: Foundations of hedonic psychology. Russell Sage Foundation, New York, NY.

Kamis, A., Koufaris, M. and Stern, T. (2008), "Using an attribute-based decision support system for user-customized products online: an experimental investigation”, MIS Quarterly, Vol. 32 No. 1, pp. 159-177.

Kellogg, D. L., Youngdahl, W. E. and Bowen, D. E. (1997), “On the relationship between customer participation and satisfaction: Two frameworks", International Journal of Service Industry Management, Vol. 8 No. 3, pp. 206-219.

Klaus, P. and Maklan, S. (2012), “EXQ: A multiple-item scale for assessing service experience”, Journal of Service Management, Vol. 23 No. 1, pp. 5-33.

Klemz, B. R. and Gruca, T. S. (2003), "Dueling or the battle royale? The impact of task complexity on the evaluation of entry threat”, Psychology \& Marketing, Vol. 20 No. 11, pp. 999-1016.

Lemke, F., Clark, M. and Wilson, H. (2011), “Customer experience quality: An exploration in business and consumer contexts using repertory grid technique”, Journal of the Academy of Marketing Science, Vol. 39 No. 6, pp. 846-869.

Lengnick-Hall, C. A. (1996), "Customer contributions to quality: A different view of the customer-oriented firm”, Academy of Management Review, Vol. 21 No. 3, pp. 791-824.

Lessne, G. and Venkatesan, M. (1989), "Reactance theory in consumer research: The past, present and future”, Advances in Consumer Research, Vol. 16 No. 1, pp. 76-78.

Levesque, C., Zuehlke, A. N., Stanek, L. R. and Ryan, R. M. (2004), “Autonomy and competence in German and American university students: A comparative study based on self-determination theory”, Journal of Educational Psychology, Vol. 96 No. 1, pp. 68-84.

McColl-Kennedy, J. R., Danaher, T. S., Gallan, A. S., Orsingher, C., Lervik-Olsen, L. and Verma, R. (2017), "How do you feel today? Managing patient emotions during health care experiences to enhance well-being”, Journal of Business Research, Vol. 79 pp. 247-259.

Meuter, M. L. and Bitner, M. J. (1998), "Self-service technologies: Extending service frameworks and identifying issues for research", in, American Marketing Association Conference Proceedings in Marketing Theory and Applications, Vol. 9, American Marketing Association, Chicago, pp. 12-19.

Mustak, M., Jaakkola, E. and Halinen, A. (2013), “Customer participation and value creation: A systematic review and research implications”, Managing Service Quality: An International Journal, Vol. 23 No. 4, pp. 341-359. 
Mustak, M., Jaakkola, E., Halinen, A. and Kaartemo, V. (2016), “Customer participation management: Developing a comprehensive framework and a research agenda”, Journal of Service Management, Vol. 27 No. 3, pp. 250-275.

Norman, D. A. and Bobrow, D. G. (1975), On the role of active memory processes in perception and cognition, in, Center for Human Information Processing, Department of Psychology, University of California, San Diego.

Ofir, C., Simonson, I. and Yoon, S. O. (2009), “The robustness of the effects of consumers' participation in market research: The case of service quality evaluations”, Journal of Marketing, Vol. 73 No. 6, pp. 105-114.

Oliver, R. L., Rust, R. T. and Varki, S. (1997), "Customer delight: Foundations, findings, and managerial insight”, Journal of Retailing, Vol. 73 No. 3, pp. 311-336.

Ostrom, A. L., Bitner, M. J., Brown, S. W., Burkhard, K. A., Goul, M., Smith-Daniels, V., Demirkan, H. and Rabinovich, E. (2010), "Moving forward and making a difference: Research priorities for the science of service”, Journal of Service Research, Vol. 13 No. 1, pp. 4-36.

Petty, R. E. and Cacioppo, J. T. (1986), The elaboration likelihood model of persuasion. In, L. Berkowitz (Ed.), Advances in experimental social psychology (Vol. 19, pp. 123205). New York: Academic Press.

Ramaswamy, V. and Gouillart, F. (2010), “Building the co-creative enterprise”, Harvard Business Review, Vol. 88 No. 10, pp. 100-109.

Ranjan, K. R. and Read, S. (2016), "Value co-creation: Concept and measurement”, Journal of the Academy of Marketing Science, Vol. 44 No. 3, pp. 290-315.

Rodie, A. R. and Kleine, S. S. (2000), "Customer participation in services production and delivery”, In, T. A. Swartz and D. Iacobucci, (Eds.), Handbook of services marketing and management, Thousand Oaks, Sage Publications, California, pp. 111-125.

Rosenbaum, M., Corus, C., Ostrom, A., Anderson, L., Fisk, R., Gallan, A., Giraldo, M., Mende, M., Mulder, M., Rayburn, S. and Shirahada, K. (2011), "Conceptualisation and aspirations of transformative service research", Journal of Research for Consumers, No. 19, pp. 1-6.

Ruiz, D. M., Gremler, D. D., Washburn, J. H. and Carrión, G. C. (2010), “Reframing customer value in a service-based paradigm: An evaluation of a formative measure in a multi-industry, cross-cultural context”, In, V. E., Vinzi, W. W., Chin, J. Henseler and H. Wang (Eds.), Handbook of partial least squares Springer, Berlin, Heidelberg, pp. 535-566.

Ryan, R. M. and Deci, E. L. (2000), "Self-determination theory and the facilitation of intrinsic motivation, social development, and well-being”, American Psychologist, Vol. 55 No. 1, pp. 68-78.

Ryan, R. M., Huta, V. and Deci, E. L. (2008), "Living well: A self-determination theory perspective on eudaimonia”, Journal of Happiness Studies, Vol. 9 No. 1, pp. 139-170. 
Ryff, C. D. and Singer, B. (2000), "Interpersonal flourishing: A positive health agenda for the new millennium”, Personality and Social Psychology Review, Vol. 4 No. 1, pp. 30-44.

Schwarz, N. (1990), "Feelings as information: Informational and motivational functions of affective states”, In, R. M. Sorrentino and E. T. Higgins (Eds.), Handbook of motivation and cognition: Foundations of social behaviour Vol. 2, Guilford Press, New York, pp. 527-561.

Schwarz, N. (2012), “Feelings-as-information theory”, In, P. A. M. Van Lange, A. Kruglanski and E. T. Higgins (Eds.), Handbook of theories of social psychology, Thousand Oaks, Sage, California, pp. 289-308.

Schwarz, N. and Clore, G. L. (1996), "Feelings and phenomenal experiences”, Social psychology: Handbook of basic principles, Vol 2, pp. 385-407.

Schwarz, N. and Clore, G. L. (2003), “Mood as information: 20 years later”, Psychological Inquiry, Vol. 14 No. 3-4, pp. 296-303.

Sharma, P., Kong, T. T. C. and Kingshott, R. P. (2016), “Internal service quality as a driver of employee satisfaction, commitment and performance: Exploring the focal role of employee well-being”, Journal of Service Management, Vol. 27 No. 5, pp. 773-797.

Sheng, X. and Zolfagharian, M. (2014), “Consumer participation in online product recommendation services: Augmenting the technology acceptance model”, Journal of Services Marketing, Vol. 28 No. 6, pp. 460-470.

Silpakit, P. and Fisk, R. P. (1985), "Participatizing the service encounter: A theoretical framework”, in, Services marketing in a changing environment, American Marketing Association, Chicago, IL, pp. 117-121.

Sirgy, M. J. and Lee, D. J. (2008), “Well-being marketing: An ethical business philosophy for consumer goods firms”, Journal of Business Ethics, Vol. 77 No. 4, pp. 377-403.

Speier, C. and Morris, M. G. (2003), “The influence of query interface design on decisionmaking performance”, MIS Quarterly, Vol. 27 No. 3, pp. 397-423.

Vargo, S. L. and Lusch, R. F. (2008), “Service-dominant logic: Continuing the evolution”, Journal of the Academy of Marketing Science, Vol. 36 No. 1, pp. 1-10.

Vargo, S. L. and Lusch, R. F. (2016). "Institutions and axioms: An extension and update of service-dominant logic”, Journal of the Academy of Marketing Science, Vol. 44 No. 1, pp. 5-23.

Verma, R. and Plaschka, G. (2003), “The art and science of customer-choice modeling: Reflections, advances, and managerial implications”, Cornell Hotel and Restaurant Administration Quarterly, Vol. 44 No. 5-6, pp. 156-165.

Voss, G. B., Parasuraman, A. and Grewal, D. (1998), “The roles of price, performance, and expectations in determining satisfaction in service exchanges”, Journal of Marketing, Vol. 62 No 4, pp. 46-61. 
Wood, R. E. (1986), “Task complexity: Definition of the construct”, Organizational Behavior and Human Decision Processes, Vol. 37 No. 1, pp. 60-82.

Wood, S., Van Veldhoven, M., Croon, M. and de Menezes, L. M. (2012), “Enriched job design, high involvement management and organizational performance: The mediating roles of job satisfaction and well-being”, Human Relations, Vol. 65 No. 4, pp. 419-445.

Woodruff, R. B. (1997), “Customer value: The next source for competitive advantage”, Journal of the Academy of Marketing Science, Vol. 25 No. 2, pp. 139-153.

Wu, C. H. J. (2011), “A re-examination of the antecedents and impact of customer participation in service”, The Service Industries Journal, Vol. 31 No. 6, pp. 863-876.

Yim, C. K., Chan, K. W. and Lam, S. S. (2012), "Do customers and employees enjoy service participation? Synergistic effects of self-and other-efficacy”, Journal of Marketing, Vol. 76 No. 6, pp. 121-140.

Zeithaml, V. A. (1988), “Consumer perceptions of price, quality, and value: A means-end model and synthesis of evidence”, Journal of Marketing, Vol. 52 No. 3, pp. 2-22.

Zhao, Y., Yan, L. and Keh, H. T. (2018), “The effects of employee behaviours on customer participation in the service encounter: The mediating role of customer emotions", European Journal of Marketing, Vol. 52 No. 5/6, pp. 1203-1222.

Zhong, J. Y. and Mitchell, V. W. (2010), “A mechanism model of the effect of hedonic product consumption on well-being”, Journal of Consumer Psychology, Vol. 20 No. 2, pp. 152-162.

Zhong, J. Y. and Mitchell, V. W. (2012), "Does consumer well-being affect hedonic consumption?” Psychology \& Marketing, Vol. 29 No. 8, pp. 583-594.

Zigurs, I. and Buckland, B. K. (1998), "A theory of task/technology fit and group support systems effectiveness”, MIS Quarterly, Vol. 22 No. 3, pp. 313-334. 
Figure 1 Proposed conceptual model

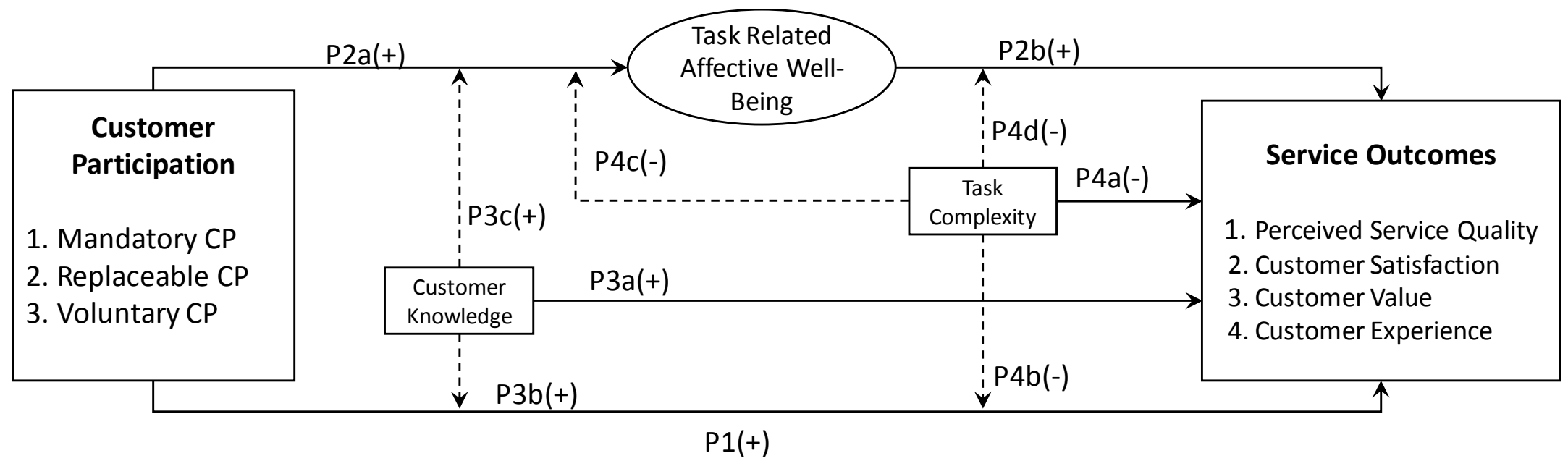


Table I Comparison of customer participation conceptualizations and its relation to other constructs

\begin{tabular}{|c|c|c|c|c|}
\hline Authors & Research Focus & Approach & Components of CP Examined & Relation of CP to other constructs \\
\hline $\begin{array}{l}\text { Cermak et al. } \\
\text { (1994) }\end{array}$ & $\begin{array}{l}\text { Role of CP in } \\
\text { service specification } \\
\text { and delivery }\end{array}$ & $\begin{array}{l}\text { Conceptualized CP to } \\
\text { include coproduction } \\
\text { in services }\end{array}$ & $\begin{array}{l}\text { Focused on R (e.g., customer } \\
\text { takes part extensively in } \\
\text { specifying the requirements) }\end{array}$ & $\begin{array}{l}\text { Positively influences service quality, } \\
\text { satisfaction, and future intentions }\end{array}$ \\
\hline $\begin{array}{l}\text { Lengnick-Hall } \\
\text { (1996) }\end{array}$ & $\begin{array}{l}\text { Roles played by the } \\
\text { customer in creating } \\
\text { quality }\end{array}$ & $\begin{array}{l}\text { Conceptualized CP to } \\
\text { include coproduction }\end{array}$ & $\begin{array}{l}\text { Focused on R (e.g., firm gives } \\
\text { opportunity for coproduction) }\end{array}$ & $\begin{array}{l}\mathrm{CP} \text { positively influence the quality of } \\
\text { production process and outcomes }\end{array}$ \\
\hline $\begin{array}{l}\text { Kellogg et al. } \\
\text { (1997) }\end{array}$ & $\begin{array}{l}\text { Influence of CP on } \\
\text { their satisfaction }\end{array}$ & $\begin{array}{l}\text { Conceptualized CP as } \\
\text { discretionary actions } \\
\text { by customers }\end{array}$ & $\begin{array}{l}\text { Focused on V (e.g., customers } \\
\text { collect information to prepare } \\
\text { for the encounter) }\end{array}$ & $\begin{array}{l}\text { CP positively relates to satisfactory } \\
\text { service outcomes }\end{array}$ \\
\hline Bitner et al. (1997) & $\begin{array}{l}\text { Roles of customers } \\
\text { in producing quality } \\
\text { in service } \\
\text { experience }\end{array}$ & $\begin{array}{l}\text { Classified services } \\
\text { based on levels of CP } \\
\text { into low CP, medium } \\
\text { CP, high CP }\end{array}$ & $\begin{array}{l}\text { Focused on } \mathrm{M} \text { and } \mathrm{R} \text { but not } \mathrm{V} \\
\text { (e.g., voluntary behaviors to } \\
\text { improve transactions is not } \\
\text { considered) }\end{array}$ & $\begin{array}{l}\text { CP positively influences satisfaction } \\
\text { with the service (both outcome and } \\
\text { provider) that improves the service } \\
\text { experience. }\end{array}$ \\
\hline $\begin{array}{l}\text { Ennew and Binks } \\
\text { (1999) }\end{array}$ & $\begin{array}{l}\text { Influence of } \mathrm{CP} \text { on } \\
\text { quality, satisfaction, } \\
\text { and retention }\end{array}$ & $\begin{array}{l}\text { Conceptualized CP as } \\
\text { joint production } \\
\text { between customers } \\
\text { and employees }\end{array}$ & $\begin{array}{l}\text { Focused on R (e.g., share } \\
\text { information, closer personal } \\
\text { contacts) }\end{array}$ & $\begin{array}{l}\text { CP is insignificant towards service } \\
\text { quality, satisfaction, and customer } \\
\text { retention however employee } \\
\text { participation was viewed positive }\end{array}$ \\
\hline $\begin{array}{l}\text { Bendapudi and } \\
\text { Leone (2003) }\end{array}$ & $\begin{array}{l}\text { Psychological } \\
\text { implication of CP in } \\
\text { coproduction }\end{array}$ & $\begin{array}{l}\text { Conceptualized CP as } \\
\text { participation and non- } \\
\text { participation }\end{array}$ & $\begin{array}{l}\text { Focused on R (e.g., customer } \\
\text { can choose to coproduce or not } \\
\text { to coproduce) }\end{array}$ & $\begin{array}{l}\text { Satisfaction with the firm varies based } \\
\text { on CP and choice to participate } \\
\text { enhances the satisfaction }\end{array}$ \\
\hline $\begin{array}{l}\text { Halbesleben and } \\
\text { Buckley (2004) }\end{array}$ & $\begin{array}{l}\text { Role played by } \\
\text { customers as human } \\
\text { resources }\end{array}$ & $\begin{array}{l}\text { Conceptualized that } \\
\text { customer replaces or } \\
\text { partners employee }\end{array}$ & $\begin{array}{l}\text { Focused on R (e.g., ATMs, self- } \\
\text { service gas station, consulting, } \\
\text { healthcare) }\end{array}$ & $\begin{array}{l}\text { CP proposed to influence productivity, } \\
\text { efficiency, performance, and } \\
\text { satisfaction }\end{array}$ \\
\hline $\begin{array}{l}\text { Bolton and Saxena- } \\
\text { Iyer (2009) }\end{array}$ & $\begin{array}{l}\text { Role of CP on } \\
\text { effective creation }\end{array}$ & $\begin{array}{l}\text { Conceptualized CP to } \\
\text { include coproduction }\end{array}$ & $\begin{array}{l}\text { Focused on mixed M, R, and V } \\
\text { on interactive service only (e.g., }\end{array}$ & $\begin{array}{l}\text { Explains customer behavioral outcomes } \\
\text { like referrals, word of mouth, }\end{array}$ \\
\hline
\end{tabular}




\begin{tabular}{|c|c|c|c|c|}
\hline & $\begin{array}{l}\text { and delivery of } \\
\text { interactive services }\end{array}$ & $\begin{array}{l}\text { (in-role) and } \\
\text { cocreation (extra-role) }\end{array}$ & online games, online banking) & $\begin{array}{l}\text { community interactions and firm } \\
\text { outcomes like profit }\end{array}$ \\
\hline Chan et al. (2010) & $\begin{array}{l}\text { Role of CP in value } \\
\text { creation and its } \\
\text { influence on service } \\
\text { outcomes }\end{array}$ & $\begin{array}{l}\text { Conceptualized CP to } \\
\text { different levels (low } \\
\text { and high) }\end{array}$ & $\begin{array}{l}\text { Focused on } \mathrm{M} \text { and } \mathrm{R} \text { but not } \mathrm{V} \\
\text { (e.g., voluntary behaviors to } \\
\text { improve value creation is not } \\
\text { considered) }\end{array}$ & $\begin{array}{l}\text { CP improves customer satisfaction and } \\
\text { hampers job satisfaction of the } \\
\text { employee }\end{array}$ \\
\hline $\begin{array}{l}\text { Mustak et al. } \\
\text { (2013) }\end{array}$ & $\begin{array}{l}\text { Summarizes the } \\
\text { conceptualization } \\
\text { and outcomes of CP }\end{array}$ & $\begin{array}{l}\text { Reviewed evolution } \\
\text { of CP (productive } \\
\text { labor, various } \\
\text { customer roles) }\end{array}$ & $\begin{array}{l}\text { Included M, R, and V without } \\
\text { differentiation (e.g., partial } \\
\text { employee, quality evaluator, } \\
\text { information exchange) }\end{array}$ & $\begin{array}{l}\text { Summarized the positive and negative } \\
\text { value outcomes for the sellers and } \\
\text { customers }\end{array}$ \\
\hline $\begin{array}{l}\text { Sheng and } \\
\text { Zolfagharian } \\
\text { (2014) }\end{array}$ & $\begin{array}{l}\text { Role of CP while } \\
\text { using online product } \\
\text { recommendation } \\
\text { agents }\end{array}$ & $\begin{array}{l}\text { Conceptualized that } \\
\text { employee supports } \\
\text { customers in } \\
\text { information search }\end{array}$ & $\begin{array}{l}\text { Focused on } \mathrm{R} \text { (e.g., screen } \\
\text { product alternatives to provide } \\
\text { best recommendations) }\end{array}$ & CP influences behavioral intentions \\
\hline Dong (2015) & $\begin{array}{l}\text { Role of CP in } \\
\text { producing versus } \\
\text { designing }\end{array}$ & $\begin{array}{l}\text { Conceptualized CP as } \\
\text { in-role behavior }\end{array}$ & $\begin{array}{l}\text { Focused on R by contributing to } \\
\text { physical labor or sharing } \\
\text { information (e.g., assembling } \\
\text { frame, designing frame) }\end{array}$ & $\begin{array}{l}\mathrm{CP} \text { influences value co-creation and } \\
\text { choice of participation based on CP } \\
\text { producing versus designing }\end{array}$ \\
\hline $\begin{array}{l}\text { Dong and } \\
\text { Sivakumar (2015) }\end{array}$ & $\begin{array}{l}\text { Propose a } \\
\text { classification of CP } \\
\text { in services }\end{array}$ & $\begin{array}{l}\text { Conceptualized CP as } \\
\text { employee in-role } \\
\text { behavior }\end{array}$ & $\begin{array}{l}\text { Focused on R (e.g., customer or } \\
\text { firm can design shoes to be } \\
\text { purchased by customer) }\end{array}$ & $\begin{array}{l}\text { Proposes the influence of CP on service } \\
\text { outcomes such as satisfaction and } \\
\text { efficiency }\end{array}$ \\
\hline Dong et al. (2015) & $\begin{array}{l}\text { Role of customer } \\
\text { participation on } \\
\text { service outcomes } \\
\text { moderated by } \\
\text { participation } \\
\text { readiness }\end{array}$ & $\begin{array}{l}\text { Classified services } \\
\text { based on levels of CP } \\
\text { into low CP, medium } \\
\text { CP, high CP }\end{array}$ & $\begin{array}{l}\text { Focused on } \mathrm{M} \text { and } \mathrm{R} \text { but not } \mathrm{V} \\
\text { (e.g., voluntary behaviors to } \\
\text { improve experience is not } \\
\text { considered) }\end{array}$ & $\begin{array}{l}\text { CP positively influence perceived } \\
\text { service quality and satisfaction }\end{array}$ \\
\hline $\begin{array}{l}\text { Flores and } \\
\text { Vasquez-Parraga } \\
\text { (2015) }\end{array}$ & $\begin{array}{l}\text { Role of choice to } \\
\text { participate in value } \\
\text { cocreation and }\end{array}$ & $\begin{array}{l}\text { Classified CP as in- } \\
\text { role with choice and } \\
\text { no choice }\end{array}$ & $\begin{array}{l}\text { Focused on } \mathrm{M} \text { and } \mathrm{R} \text { but not } \mathrm{V} \\
\text { (e.g., no choice makes it } \mathrm{M} \text { and } \\
\text { choice makes it } \mathrm{R} \text { ) }\end{array}$ & $\begin{array}{l}\mathrm{R} \text { had a strong positive relation towards } \\
\text { satisfaction mediated through relational } \\
\text { and economic value compared to } \mathrm{M}\end{array}$ \\
\hline
\end{tabular}




\begin{tabular}{|l|l|l|l|l|}
\hline & satisfaction & & \\
\hline $\begin{array}{l}\text { Chen and Wang } \\
\text { (2016) }\end{array}$ & $\begin{array}{l}\text { Role of CP in value } \\
\text { cocreation and } \\
\text { customer loyalty }\end{array}$ & $\begin{array}{l}\text { Conceptualized CP in } \\
\text { the context of self- } \\
\text { service technologies }\end{array}$ & $\begin{array}{l}\text { Focused on M (e.g., self-check- } \\
\text { in kiosk, online check-in } \\
\text { system) }\end{array}$ & $\begin{array}{l}\text { M positively relates to enjoyment, } \\
\text { economic and relational values, which } \\
\text { further leads to satisfaction towards } \\
\text { system and company }\end{array}$ \\
\hline $\begin{array}{l}\text { Mustak } \text { et al. } \\
(2016)\end{array}$ & $\begin{array}{l}\text { Propose a } \\
\text { framework on } \\
\text { constituents of CP } \\
\text { management }\end{array}$ & $\begin{array}{l}\text { Conceptualized CP } \\
\text { inputs as labor and } \\
\text { task, information and } \\
\text { knowledge, behavior }\end{array}$ & $\begin{array}{l}\text { Focused mostly on M and R but } \\
\text { not V (e.g., labor and task } \\
\text { specify on in-role participation) }\end{array}$ & $\begin{array}{l}\text { Summarized the positive and negative } \\
\text { value outcomes for the sellers and } \\
\text { customers }\end{array}$ \\
\hline $\begin{array}{l}\text { Ranjan and Read } \\
\text { (2016) }\end{array}$ & $\begin{array}{l}\text { Examines cocreation } \\
\text { and influence on } \\
\text { satisfaction }\end{array}$ & $\begin{array}{l}\text { Conceptualized } \\
\text { cocreation into } \\
\text { coproduction and } \\
\text { value in use }\end{array}$ & $\begin{array}{l}\text { Focused on mixed M, R, and V } \\
\text { (e.g., knowledge sharing, } \\
\text { interaction) }\end{array}$ & $\begin{array}{l}\text { Cocreation positively relates to } \\
\text { satisfaction }\end{array}$ \\
\hline $\begin{array}{l}\text { Dong and } \\
\text { Sivakumar (2017) }\end{array}$ & $\begin{array}{l}\text { to increase } \\
\text { conceptual clarity }\end{array}$ & $\begin{array}{l}\text { Classifies CP into M, } \\
\text { R, and V based on } \\
\text { criticality of service } \\
\text { provision and entity } \\
\text { involved in provision }\end{array}$ & $\begin{array}{l}\text { Focusses on M, R, and V and } \\
\text { distinguishes the three from one } \\
\text { another }\end{array}$ & No proposed outcomes \\
\hline Chen (2018) & $\begin{array}{l}\text { Role of CP in } \\
\text { service failure } \\
\text { attribution }\end{array}$ & $\begin{array}{l}\text { Classifies CP as low } \\
\text { and high }\end{array}$ & $\begin{array}{l}\text { Focused mostly on M and R but } \\
\text { not V (e.g., task intensive in- } \\
\text { role participation) }\end{array}$ & $\begin{array}{l}\text { Customers with high self-efficacy } \\
\text { attribute service failure when CP was } \\
\text { high }\end{array}$ \\
\hline
\end{tabular}

CP = Customer Participation, $\mathrm{M}$ = Mandatory CP, R = Replaceable CP, V = Voluntary CP 
Table II Literature on influence of customer participation on service outcomes

\begin{tabular}{|c|c|c|c|c|}
\hline Outcomes & Types of CP & Positive effects with CP & $\begin{array}{l}\text { Negative effects } \\
\text { with CP }\end{array}$ & $\begin{array}{l}\text { Non-significant } \\
\text { effects with CP }\end{array}$ \\
\hline \multirow{3}{*}{$\begin{array}{l}\text { Customer } \\
\text { Satisfaction }\end{array}$} & Mandatory Participation & $\begin{array}{l}\text { Chan et al. (2010), Yim et al. (2012), Yoo et al. } \\
\text { (2012), Gallan et al. (2013), Agarwal and Basu } \\
\text { (2014), Dong et al. (2015), Sweeney et al. (2015), } \\
\text { Dong et al. (2016) }\end{array}$ & $\begin{array}{l}\text { Wu (2011), } \\
\text { Heidenreich et al. } \\
\text { (2015) }\end{array}$ & $\begin{array}{l}\text { Ennew and } \\
\text { Binks (1999) }\end{array}$ \\
\hline & Replaceable Participation & $\begin{array}{l}\text { Cermak et al. (1994), Dong et al. (2008), Chan et al. } \\
\text { (2010), Hunt et al. (2012), Yim et al. (2012), Gallan } \\
\text { et al. (2013), Heidenreich et al. (2015), Dong et al. } \\
\text { (2015), Sweeney et al. (2015), Dong et al. (2016) }\end{array}$ & $\begin{array}{l}\text { Bendapudi and } \\
\text { Leone (2003), Wu } \\
\text { (2011), Haumann } \\
\text { et al. (2015) }\end{array}$ & $\begin{array}{l}\text { Ennew and } \\
\text { Binks (1999) }\end{array}$ \\
\hline & Voluntary Participation & $\begin{array}{l}\text { Kellogg et al. (1997), Chan et al. (2010), Yim et al. } \\
\text { (2012), Yoo et al. (2012), Gallan et al. (2013), } \\
\text { Sweeney et al. (2015) }\end{array}$ & Wu (2011) & $\begin{array}{l}\text { Ennew and } \\
\text { Binks (1999) }\end{array}$ \\
\hline \multirow{3}{*}{$\begin{array}{l}\text { Service } \\
\text { Quality }\end{array}$} & Mandatory Participation & $\begin{array}{l}\text { Claycomb et al. (2001), Yoo et al. (2012), Gallan et } \\
\text { al. (2013), Amorim et al. (2014), Dong et al. (2015), } \\
\text { Sweeney et al. (2015) }\end{array}$ & & $\begin{array}{l}\text { Ennew and } \\
\text { Binks (1999) }\end{array}$ \\
\hline & Replaceable Participation & $\begin{array}{l}\text { Cermak et al. (1994), Claycomb et al. (2001), Gallan } \\
\text { et al. (2013), Amorim et al. (2014), Dong et al. } \\
\text { (2015), Sweeney et al. (2015) }\end{array}$ & & $\begin{array}{l}\text { Ennew and } \\
\text { Binks (1999) }\end{array}$ \\
\hline & Voluntary Participation & $\begin{array}{l}\text { Kellogg et al. (1997), Claycomb et al. (2001), Yoo et } \\
\text { al. (2012), Gallan et al. (2013), Sweeney et al. } \\
\text { (2015) }\end{array}$ & & $\begin{array}{l}\text { Ennew and } \\
\text { Binks (1999) }\end{array}$ \\
\hline \multirow{3}{*}{$\begin{array}{l}\text { Perceived } \\
\text { Value }\end{array}$} & Mandatory Participation & Yi and Gong (2013) & & \\
\hline & Replaceable Participation & Yi and Gong (2013), Dong (2015) & Dong (2015) & \\
\hline & Voluntary Participation & Yi and Gong (2013) & & \\
\hline
\end{tabular}

$\mathrm{CP}=$ Customer Participation 
Table III Proposed directions for future research

\begin{tabular}{|c|c|}
\hline $\begin{array}{l}\text { Key } \\
\text { research } \\
\text { domains }\end{array}$ & Proposed research questions \\
\hline $\begin{array}{l}\text { Types of } \\
\text { Customer } \\
\text { participation }\end{array}$ & $\begin{array}{l}\text { 1. Which factors (e.g. customer, service provider, context, or situation) could influence the types of participation? } \\
\text { 2. What is the influence of three types of participation to specific outcomes? } \\
\text { 3. How do the types of participation influence various services contexts and what are the implications? } \\
\text { 4. Do the types of participation co-occur? How they interact with one another? How does the interaction influence the various outcomes? } \\
\text { 5. How do the types of participation relate to other related constructs (e.g., customer involvement, engagement, and innovation, etc.)? } \\
\text { 6. Does social media influence the types of participation and if so what is its influence on service outcomes? }\end{array}$ \\
\hline Well-Being & $\begin{array}{l}\text { 1. How can participation types influence well-being? Does it partially mediate all service outcomes? } \\
\text { 2. What are the different types of well-being and how do participation types influence them? Will there be any difference in the types of well-being } \\
\text { that are affected based on the types of participation? } \\
\text { 3. Does the influence of customer participation on well-being vary with the service context? In what all context participation influences the } \\
\text { eudaimonic well-being? } \\
\text { 4. Does customer participation influence employee well-being? What are the positive or negative effects of this on service outcomes? } \\
\text { 5. How long will the influence of participation on their well-being stay with the customer? Does the duration influence the service outcomes } \\
\text { positively? } \\
\text { 6. How does influence of participation on well-being transform the lives of customers? What are the outcomes of well-being that could transform } \\
\text { the lives of customer or employees? }\end{array}$ \\
\hline $\begin{array}{l}\text { Intervening } \\
\text { factors that } \\
\text { impact } \\
\text { types of } \\
\text { customer } \\
\text { participation }\end{array}$ & $\begin{array}{l}\text { 1. How does the influence of different types of customer participation on service outcomes vary based on customer-specific, provider-specific } \\
\text { factors, context-specific factors? } \\
\text { 2. How does situation or the individual's (customer/employees) influence the impact of types of participation on service outcomes? } \\
\text { 3. How do personal characteristics of individual (customer/employee) influence the impact of participation types on service outcomes? } \\
\text { 4. What is the influence of culture on the influence of participation types on service outcomes? How does participation types vary based on } \\
\text { intercultural service encounter? }\end{array}$ \\
\hline
\end{tabular}

